\title{
Health promotion programs in higher education: integrative review of the literature
}

\author{
Programas de promoção da saúde no ensino superior: revisão integrativa de literatura \\ Programas de promoción de la salud en la enseñanza superior: revisión integrativa de literatura
}

Fernanda Maria Príncipe Bastos Ferreira', Irma da Silva Brito", Margarida Reis Santos ${ }^{\text {III }}$

' Escola Superior de Enfermagem da Cruz Vermelha Portuguesa de Oliveira de Azeméis. Oliveira de Azeméis, Portugal. "Escola Superior de Enfermagem de Coimbra. Coimbra, Portugal.

II' Escola Superior de Enfermagem do Porto. Porto, Portugal.

How to cite this article:

Ferreira FMPB, Brito IS, Santos MR. Health promotion programs in higher education: integrative review of the literature. Rev Bras Enferm [Internet]. 2018;71(Suppl 4):1714-23. [Thematic Issue: Education and teaching in Nursing] DOI: http://dx.doi.org/10.1590/0034-7167-2016-0693

Submission: 02-22-2016 Approval: 06-07-2017

\begin{abstract}
Objective: to characterize the interventions of health promotion programs implemented in Health Promoting Universities; to analyze the results of the interventions of health promotion programs. Method: integrative review carried out in EBSCO, PubMed, SciELO, Scopus and Web of Science. Articles published between 2000 and 2014 were selected, with evidence of health promotion intervention programs and evaluation of results. Results: 17 articles were included. The health promotion programs aimed at increasing the welfare of students, with an emphasis on physical activity, sexual health and on improving the environment of health support within the university community. Conclusion: health promotion strategies in an university context do not always result from the convergence between educational, political, legislative or organizational actions that support lifestyles and conditions which are favorable to the health of individuals or groups, and that contribute to improving the physical and social environment.

Descriptors: Health Promotion; Universities; Students; Community Participation; Education in Nursing.
\end{abstract}

\section{RESUMO}

Objetivo: caraterizar as intervenções dos programas de promoção da saúde implementados em Universidades Promotoras de Saúde; analisar os resultados das intervenções dos programas de promoção da saúde. Método: revisão integrativa realizada na EBSCO, PubMed, SciELO, Scopus e Web of Science. Selecionaram-se artigos publicados entre os anos de 2000 e 2014 , com evidências de programas de intervenção de promoção da saúde e avaliação de resultados. Resultados: foram incluídos 17 artigos. Os programas de promoção da saúde visavam aumentar o bem-estar dos estudantes, com ênfase na atividade física, saúde sexual e melhoria do ambiente de suporte à saúde no âmbito da comunidade universitária. Conclusão: as estratégias de promoção da saúde em contexto universitário nem sempre resultam da convergência entre ações educativas, políticas, legislativas ou organizacionais que apoiam estilos de vida e condições favoráveis à saúde dos indivíduos ou coletividades e que contribuem para melhoria do ambiente físico e social.

Descritores: Promoção da Saúde; Universidades; Estudantes; Participação Comunitária; Educação em Enfermagem.

\section{RESUMEN}

Objetivo: caracterizar las intervenciones de los programas de promoción de la salud implementados en Universidades Promotoras de Salud; analizar los resultados de las intervenciones de los programas de promoción de la salud. Método: revisión integrativa realizada en la EBSCO, PubMed, SciELO, Scopus y Web of Science. Se seleccionaron artículos publicados entre los años 2000 y 2014, con evidencias de programas de intervención de promoción de la salud y evaluación de resultados. Resultados: se incluyeron 17 artículos. Los programas de promoción de la salud tenían el objetivo de aumentar el bienestar de los estudiantes, con énfasis en la actividad física, salud sexual y mejora del entorno de apoyo a la salud en el ámbito de la comunidad universitaria. Conclusión: las estrategias de promoción de la salud en el contexto universitario no siempre resultan 
de la convergencia entre acciones educativas, políticas, legislativas u organizacionales que apoyan estilos de vida e condiciones favorables a la salud de los individuos o colectividades y que contribuyen a la mejora del entorno físico y social.

Descriptores: Promoción de la Salud; Universidades; Estudiantes; Participación Comunitaria; Educación en Enfermería.

CORRESPONDING AUTHOR Fernanda Maria Príncipe Bastos Ferreira E-mail: fernandaprincipe@esenfcrpoa.eu

\section{INTRODUCTION}

Health Promoting Universities (HPU) are privileged spaces for the creation of a health promoting context for the educational community, because they improve the health profile through the development of education, of research and of knowledge sharing, which contributes to the well-being and sustainability of the community as a whole, and also for the evaluation of the effectiveness of intervention programs ${ }^{(1)}$. Health promoting spaces are intervention contexts where multilevel strategies are dynamized and knowledge is mobilized for the promotion of healthy environments and behaviors $^{(2-3)}$. These contexts are part of a set of social dynamics in which different actors learn, work, socialize and enjoy their work or leisure time and services available in favor of individual and collective health, becoming thus environments that are favorable to health and sustainable development ${ }^{(4)}$. This approach has been successfully applied in many primary and pre-university schools all over the world. In higher education, the process was not as extensive, seeing that health promotion is not the core business of these institutions. However, in seeking to integrate a health promotion commitment, it is imperative that we demonstrate and illustrate how investment in welfare can contribute to the attainment of their objectives and institutional mission ${ }^{(5)}$.

Assuming that higher education is considered to be society's pedagogical, scientific and technological vanguard, it would be desirable if, in relation to the the students' acquisition of skills, an investment in the fullness of human development was made, which can only be achieved if the entire educational system also invests in health. This aspect gains even greater relevance when good practices in the field of health promotion (HP) are adopted through autonomy, infrastructure and complex networks ${ }^{(6)}$. Higher education has the responsibility to develop strategies aimed at the qualification of students, at the promotion of self-control and, consequently, at improving health and reorienting the focus of health services, with emphasis on HP and on disease prevention through the integration of a wide set of activities and educational programs ${ }^{(7)}$.

Some authors propose a conceptual framework that contributes to the creation of healthy contexts, based on an ecological model of public health, with a systemic and holistic approach, relying on the community's organization and development to introduce and manage changes in this context, in order to integrate health and well-being in the culture and economic activities of the community in general. They suggest that such an approach should be based on certain values such as participation, equity and partnership ${ }^{(8)}$.

The American College Health Association (ACHA) develops standards of professional practices for HP in higher education ${ }^{(9)}$. As a result, the standards of Best Practices for Health Promotion in Higher Education that guide the evaluation and ensuring of the quality of HP in higher education were published ${ }^{(10)}$.
These standards include seven criteria: integration with the mission of Higher Education Institutions (HEIs); practice of a socio-ecological approach; collaborative practice; cultural competence; theory-based practice; evidence-based practice; professional enhancement and ethical practice. In line with the international recommendations of participatory practices, we stress the importance of HP programs in higher education being based on participatory action-research. This is why the inclusion of the quality standards of the International Collaboration on Participatory Health Research (ICPHR) is relevant ${ }^{(11)}$. In this sense, in the effective practice of HP in higher education, it would be desirable that institutions designed and implemented HP strategies involving students, professors and peer education, using local resources to ensure sustainability.

Based on the evidence described concerning the HP criteria in a higher education context ${ }^{(10-11)}$, it becomes appropriate to perform an integrative review of the literature which makes it possible to identify intervention strategies of HP programs implemented in HPU and analyze their results.

\section{OBJECTIVE}

To characterize the interventions of health promotion programs implemented in Health Promoting Universities; to analyze the results of the interventions of health promotion programs.

\section{METHOD}

To achieve the proposed objectives, we opted for an integrative review of the literature, a method that provides a synthesis of knowledge, because it makes it possible to gather significant study results ${ }^{(12)}$. The steps that guided the development of this review were: 1 - development of the guiding question, 2 - establishing of criteria for inclusion and exclusion of articles, 3 - definition of the information to be extracted from the selected studies, 4 - critical analysis of included studies, 5 - analysis, synthesis and presentation of results ${ }^{(12)}$.

The guiding question of the research was: What are the strategies and results obtained in the interventions of the Health Promotion programs implemented in Health Promoting Universities?

The selection of the studies was carried out by three authors, independently and concurrently, in September 2015, through online access in databases that are prominent in the Health field: EBSCO, PubMed, Scientific Electronic Library Online (SciELO), Scopus and Web of Science. Controlled keywords present among the Health Sciences Descriptors (DeCS) and terms of the Medical Subject Headings (MeSH) were combined using Boolean operators AND and OR, to develop a search strategy based on the combining of the controlled terms health promotion AND students AND consumer participation AND education, higher OR universities.

The inclusion criteria for selection of articles were: 
publications in Portuguese, English and Spanish, with full texts available on the selected databases in the 2000-2014 period, that answered the guiding question.

In total, 803 articles were found, and of these, 165 studies were identified by their title, of which 148 were excluded through the reading of the abstract, 17 articles having been included. The excluded articles had in their abstract or title HP descriptors, but referred to descriptive studies on the behavior, perceptions or opinions of university students concerning health-related issues and did not present results about intervention programs or their effectiveness (Figure 1). We also excluded the epidemiological

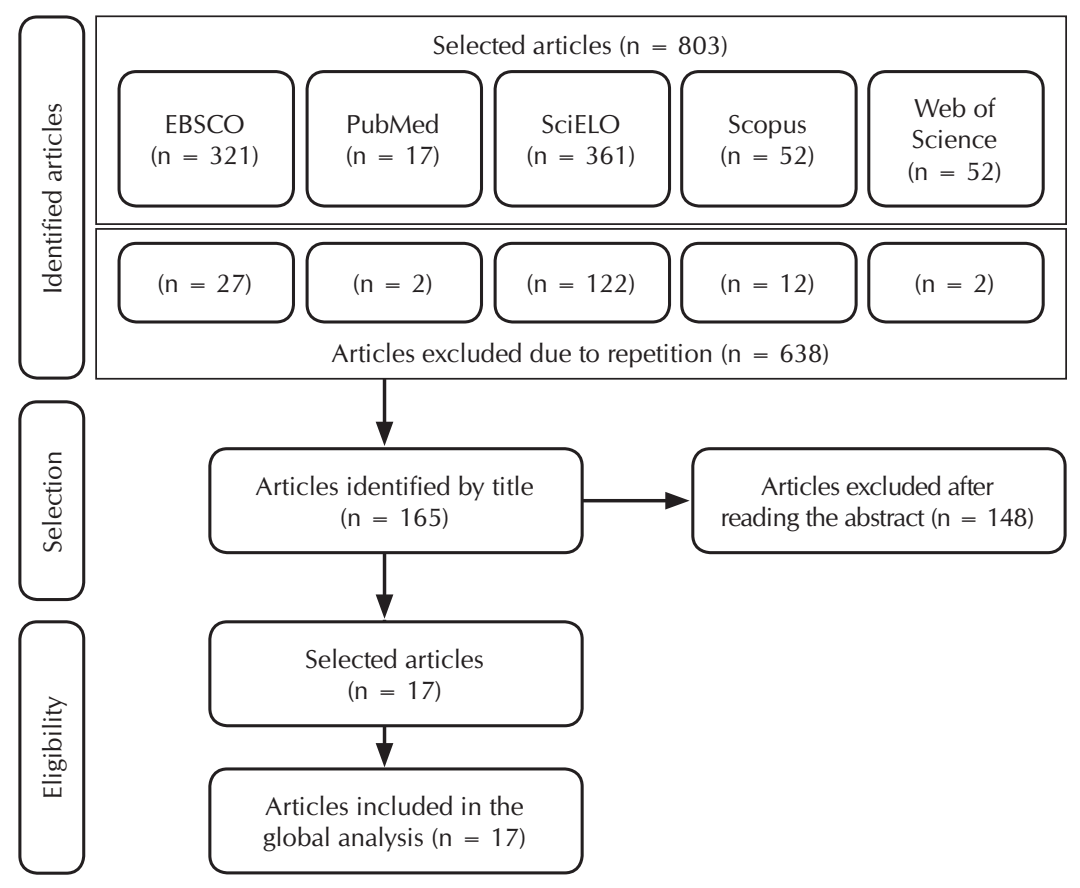

Figure 1 - Flow chart representing the selection of articles included in the integrative review and methodological studies, for not corresponding to the proposed objectives.

The analysis of the 17 articles was conducted by the investigators, two by two, in accordance with the requirements of the HPU, based on the criteria of ACHA's Best Practices for Health Promotion in Higher Education ${ }^{(10)}$. To assess the degree of participation and the results of the interventions, we based ourselves on the quality standards of participatory action-research defined by the ICPHR ${ }^{(11)}$. In the participation dimension, we considered the following categories: 1 . Contractual: people are "contracted" for HP projects and act as informants; 2. Advisory: people are invited by researchers to provide their views before the realization of interventions; 3 . Collaborative: researchers and people from the community work together on directed projects, implemented and managed by the researchers; 4. High school: researchers and people from the community work together as colleagues and share their different skills in a process of mutual learning. In the dimension of results obtained, we considered the extension of implementation of programs included in the HPU, their impact and health policies.

To facilitate the examination of articles, a summary table was elaborated (Chart 1), in which the following items are described: author, country/year, objectives, participants, interventions/program, in order to enhance our understanding of the findings.

The interpretative analysis of the results of the articles included in the review was operationalized in a table that guided the critical analysis of the content of the selected articles, by closed procedure, based on the criteria for this integrative review (Chart 2). This analysis allowed the characterization of HP programs based on the $\mathrm{ACHA}^{(10)}$ criteria, on the $\mathrm{ICPHR}^{(11)}$ and on the results of the programs.

Chart 1 - Summary of articles that composed the integrative review

\begin{tabular}{|c|c|c|c|c|c|}
\hline & Author & $\begin{array}{c}\text { Country/ } \\
\text { Year }\end{array}$ & Objectives & Participants & Interventions/Program \\
\hline 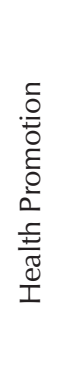 & $\begin{array}{l}\text { Xiangyang } \\
\text { T, Lan Z, } \\
\text { Xueping } \\
\text { M, Tao Z, } \\
\text { Yuzhen S, } \\
\text { Jagusztyn } \text { M }^{(7)}\end{array}$ & $\begin{array}{l}\text { China/ } \\
2003\end{array}$ & $\begin{array}{l}\text { To create health promoting } \\
\text { universities based on the } \\
\text { principles of the Ottawa Charter } \\
\text { for health promotion. } \\
\text { To improve the environment } \\
\text { of health support within the } \\
\text { university community. } \\
\text { To empower the members of the } \\
\text { university community so that } \\
\text { they can improve and preserve } \\
\text { their own health and that of } \\
\text { others. }\end{array}$ & $\begin{array}{l}\text { Educational } \\
\text { community, local } \\
\text { government, health } \\
\text { institutions and } \\
\text { expert advice in } \\
\text { health education, } \\
\text { the World Health } \\
\text { Organization. }\end{array}$ & $\begin{array}{l}\text { Peer education and health education programs. } \\
\text { Creation of health services (smoking cessation, } \\
\text { mental health and prevention of STI/AIDS, } \\
\text { nutrition). } \\
\text { To implement community activities with the } \\
\text { participation of the students. Reformulation } \\
\text { of policies of the university in order to } \\
\text { promote the health of students, professors and } \\
\text { administrative staff. } \\
\text { Creating a healthy physical and social } \\
\text { environment. Curricular integration of a } \\
\text { discipline of health education. }\end{array}$ \\
\hline
\end{tabular}


Chart 1

\begin{tabular}{|c|c|c|c|c|}
\hline Author & $\begin{array}{l}\text { Country/ } \\
\text { Year }\end{array}$ & Objectives & Participants & Interventions/Program \\
\hline Prieto $\mathrm{RA}^{(13)}$ & $\begin{array}{l}\text { Colombia/ } \\
2003\end{array}$ & $\begin{array}{l}\text { To design a model of health } \\
\text { promotion focused on physical } \\
\text { activity within the academic } \\
\text { community. }\end{array}$ & $\begin{array}{l}\text { College students } \\
\text { and health } \\
\text { professionals }\end{array}$ & $\begin{array}{l}\text { Multidimensional model: identification of needs; } \\
\text { development, validation and implementation of } \\
\text { the program. Free sports courses, dance groups; } \\
\text { therapeutic assistance; } 2 \text { open seminars; direct } \\
\text { assistance to athletes. The activities have been } \\
\text { included in the curricular spaces. }\end{array}$ \\
\hline $\begin{array}{l}\text { Moskovics } \\
\text { JM, Calvetti } \\
\text { PÜ'(14) }\end{array}$ & $\begin{array}{l}\text { Spain/ } \\
2008\end{array}$ & $\begin{array}{l}\text { To describe the experience of } \\
\text { a training course aimed at the } \\
\text { prevention of STD/AIDS. }\end{array}$ & Master's Students & $\begin{array}{l}\text { Training workshops developed by psychologists. } \\
\text { The course had } 15 \mathrm{~h} \text { duration and lasted three } \\
\text { weeks, having been made up of five } 3 \mathrm{~h} \text { meetings, } \\
\text { with workshops on sexuality, STD/AIDS, } \\
\text { drugs and development of projects. Activities } \\
\text { were carried out based on a participatory and } \\
\text { problematization methodology. Experiential } \\
\text { techniques related to vulnerability, prevention, } \\
\text { health promotion and protagonism were } \\
\text { discussed. Multiplying agents were trained, and } \\
\text { a space for education/reflection was created with } \\
\text { the aim of raising awareness on the emotions } \\
\text { and values involved, as well as on the knowledge } \\
\text { related to the prevention of STD/AIDS. }\end{array}$ \\
\hline $\begin{array}{l}\text { Tavares J, } \\
\text { Pereira A, } \\
\text { Gomes AA, } \\
\text { Cabral AP, } \\
\text { Fernandes } \\
\text { C, Huet I, et } \\
\text { al. }{ }^{(15)}\end{array}$ & $\begin{array}{l}\text { Portugal/ } \\
2006\end{array}$ & $\begin{array}{l}\text { To present a curricular } \\
\text { intervention within the scope } \\
\text { of an optional discipline } \\
\text { called Strategies for Promoting } \\
\text { Academic Success in Higher } \\
\text { Education. }\end{array}$ & $\begin{array}{l}\text { University students } \\
\text { and professors }\end{array}$ & $\begin{array}{l}\text { Preparatory sessions and reflection on a theme, } \\
\text { followed by plenary sessions ("Rhythm of } \\
\text { sleep and wakefulness in college students and } \\
\text { academic success"; "Literacy and academic } \\
\text { success"; "Techniques of speech and presentation } \\
\text { of papers"; "Learning experiences and academic } \\
\text { self-regulation"; "Promotion of health and } \\
\text { wellness in higher education".) These could be } \\
\text { developed by the students themselves (or experts } \\
\text { invited by them), with online access. }\end{array}$ \\
\hline $\begin{array}{l}\text { Cabrera RA, } \\
\text { Ramos GS, } \\
\text { Palú MEC, } \\
\text { Cáceres BP } \\
\text { (16) }\end{array}$ & $\begin{array}{l}\text { Cuba/ } \\
2013\end{array}$ & $\begin{array}{l}\text { Promoting the sexual and } \\
\text { reproductive health of } \\
\text { students. }\end{array}$ & University students & $\begin{array}{l}\text { Focus groups and in-depth interviews; training } \\
\text { and communication workshops; radio program } \\
\text { and newspapers; personalized counseling. An } \\
\text { improvement in the students' knowledge was } \\
\text { verified. }\end{array}$ \\
\hline $\begin{array}{l}\text { Mello MVO, } \\
\text { Junior BR, } \\
\text { Menossi BRS, } \\
\text { Vieira FSF }^{(17)}\end{array}$ & $\begin{array}{l}\text { Brazil/ } \\
2014\end{array}$ & $\begin{array}{l}\text { To promote healthy lifestyles } \\
\text { through the use of social } \\
\text { networks. }\end{array}$ & Students & $\begin{array}{l}\text { Posts with preventive messages: physical activity, } \\
\text { eating habits; drugs; diseases; sexual activity; } \\
\text { security and traffic. } \\
\text { An increase in the use of social networks was } \\
\text { verified. }\end{array}$ \\
\hline $\begin{array}{l}\text { Alvarez } M_{1} \\
\text { Oliveira } M^{(18)}\end{array}$ & $\begin{array}{l}\text { Portugal/ } \\
2007\end{array}$ & $\begin{array}{l}\text { To increase behavioral skills } \\
\text { and to stimulate the adoption } \\
\text { of preventive behaviors related } \\
\text { to HIV/AIDS that do not involve } \\
\text { the consistent use of condoms } \\
\text { only, but in particular, HIV/AIDS } \\
\text { screening tests for both partners. }\end{array}$ & University students & $\begin{array}{l}\text { Training with } 6 \text { weekly sessions of } 3 \text { hours } \\
\text { each involving a control group subjected to } \\
\text { other interventions and to a pre- and post- } \\
\text { evaluation test, with a } 6 \text {-month follow-up. } \\
\text { Improvement in adherence to other preventive } \\
\text { behaviors beyond the use of condoms, such as } \\
\text { HIV/AIDS screening tests, was verified. }\end{array}$ \\
\hline $\begin{array}{l}\text { Reger B, } \\
\text { Williams } \\
\text { K, Kolar M, } \\
\text { Smith H, } \\
\text { Douglas J'(19) }\end{array}$ & USA 2002 & $\begin{array}{l}\text { To implement a welfare plan in } \\
\text { the university. }\end{array}$ & $\begin{array}{l}\text { Under and } \\
\text { graduate students, } \\
\text { professors, } \\
\text { administration, } \\
\text { staff and retired } \\
\text { volunteers, unions, } \\
\text { school doctor and } \\
\text { community leader. }\end{array}$ & $\begin{array}{l}\text { Twelve-week project, with weekly sessions } \\
\text { of participatory action, decision making and } \\
\text { problem solving. Participatory activities related } \\
\text { to healthy lifestyles, reflection, discussion and } \\
\text { planning of welfare programs, with health state } \\
\text { evaluation at the beginning and at the end of } 12 \\
\text { weeks, consisting of: anthropometric measures, } \\
\text { blood pressure, clinical analysis, in addition to a } \\
\text { health risk assessment questionnaire. } \\
\text { The project resulted in the creation of a health } \\
\text { and welfare bureau, occupational medicine } \\
\text { programs, graduate courses on management } \\
\text { and evaluation of lifestyles, reports with the } \\
\text { assessment of risk prevalence and evaluation } \\
\text { proposals. Annual conference on health and } \\
\text { welfare at the University. }\end{array}$ \\
\hline
\end{tabular}


Chart 1

\begin{tabular}{|c|c|c|c|c|c|}
\hline & Author & $\begin{array}{l}\text { Country/ } \\
\text { Year }\end{array}$ & Objectives & Participants & Interventions/Program \\
\hline \multirow{2}{*}{ 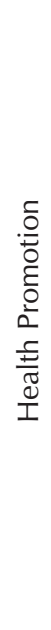 } & $\begin{array}{l}\text { Mason IG, } \\
\text { Brooking AK, } \\
\text { Oberender } \\
\text { A, Harford } \\
\text { JM, Horsley }_{\text {PG }}^{(20)}\end{array}$ & $\begin{array}{l}\text { New } \\
\text { Zealand/ } \\
2002\end{array}$ & $\begin{array}{l}\text { To manage the environment } \\
\text { and reduce waste production. }\end{array}$ & $\begin{array}{l}\text { University } \\
\text { managers, students, } \\
\text { professors and non- } \\
\text { teaching staff. }\end{array}$ & $\begin{array}{l}\text { Introduction of selective waste collection } \\
\text { systems and environmental management } \\
\text { (of energy and physical); formation of the } \\
\text { educational community. } \\
\text { Reduction in the quantity of garbage and } \\
\text { energy saving which financed } 50 \% \text { of the } \\
\text { program. A protocol of environmental } \\
\text { responsibility, curricular inclusion, creation } \\
\text { of an environmental club and involvement of } \\
\text { enterprises in waste management was signed. }\end{array}$ \\
\hline & $\begin{array}{l}\text { Healy D, Mc } \\
\text { Sharry } \mathrm{P}^{(21)}\end{array}$ & $\begin{array}{l}\text { Ireland/ } \\
2010\end{array}$ & $\begin{array}{l}\text { To promote self-awareness in } \\
\text { nursing students in relation } \\
\text { to their own health status and } \\
\text { personal behaviors. }\end{array}$ & Nursing Students & $\begin{array}{l}\text { The students had the opportunity to evaluate } \\
\text { the perceived stress in their lives and were } \\
\text { monitored in relaxation sessions guided by the } \\
\text { facilitator. The processes of teaching are focused } \\
\text { on the active participation of students through } \\
\text { the sharing of experiences. Workshops were } \\
\text { included in the curriculum of the course in } \\
\text { nursing. }\end{array}$ \\
\hline \multirow{4}{*}{ 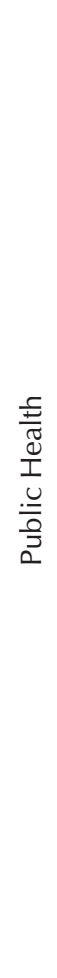 } & $\begin{array}{l}\text { Murphy BL, } \\
\text { Dipietro, NA, } \\
\text { Kier KL }\end{array}$ & USA 2010 & $\begin{array}{l}\text { To increase knowledge and the } \\
\text { use of folic acid. }\end{array}$ & $\begin{array}{l}\text { University } \\
\text { Pharmacy students }\end{array}$ & $\begin{array}{l}\text { Thirty-minute lectures, posters and messages } \\
\text { via email with evaluation before and after } 4 \\
\text { weeks. }\end{array}$ \\
\hline & $\begin{array}{l}\text { Lameiras M, } \\
\text { Ricoy MC, } \\
\text { Carrera MV, } \\
\text { Failde J M, } \\
\text { Núñez } \mathrm{AM}^{(23)}\end{array}$ & $\begin{array}{l}\text { Spain/ } \\
2011\end{array}$ & $\begin{array}{l}\text { To ascertain the satisfaction } \\
\text { with the use of the female } \\
\text { condom, as well as the } \\
\text { advantages and obstacles in } \\
\text { using it. }\end{array}$ & $\begin{array}{l}\text { University students } \\
\text { and experts }\end{array}$ & $\begin{array}{l}\text { Training workshops on contraception and sexual } \\
\text { protection with mixed groups, and groups of men } \\
\text { and women only ( } 3 \text { sessions with 1,5h each). } \\
\text { Evaluation sessions with discussion groups with } \\
45 \text { to } 60 \text { minutes duration. Increased satisfaction } \\
\text { with condom use and expansion of knowledge } \\
\text { were verified. }\end{array}$ \\
\hline & $\begin{array}{l}\text { Cabieses B, } \\
\text { Muñoz M, } \\
\text { Zuzulich S, } \\
\text { Contreras } \\
\text { A }^{(24)}\end{array}$ & $\begin{array}{l}\text { Chile/ } \\
2006\end{array}$ & $\begin{array}{l}\text { To implement the law on } \\
\text { tobacco control at the } \\
\text { university. }\end{array}$ & $\begin{array}{l}\text { Nursing academic } \\
\text { community, experts } \\
\text { and the Ministry of } \\
\text { Health }\end{array}$ & $\begin{array}{l}\text { Collaborative and sustainable work between } \\
\text { several important members of the community: } \\
\text { international contest "Quit \& Win"; World No } \\
\text { Tobacco Day; debate forum; distribution of } \\
\text { leaflets; website; public notice. Changes in health } \\
\text { and organizational policies were verified. }\end{array}$ \\
\hline & $\begin{array}{l}\text { Mendoza } \\
\text { AZ }^{(25)}\end{array}$ & $\begin{array}{l}\text { Mexico/ } \\
2005\end{array}$ & $\begin{array}{l}\text { To contribute to the reduction } \\
\text { of drug use through a } \\
\text { transforming leadership } \\
\text { process, that promotes a } \\
\text { holistic approach to health } \\
\text { promotion. }\end{array}$ & $\begin{array}{l}\text { Nursing Students } \\
\text { and the community }\end{array}$ & $\begin{array}{l}\text { Regular campaigns of promotion of health } \\
\text { education for the university and the community } \\
\text { in general; Formation of health support groups; } \\
\text { Creation of a health education system through } \\
\text { interventions in health fairs; Individualized } \\
\text { care and evaluation. Health policies have been } \\
\text { established within the academic context, in } \\
\text { conjunction with the community, as well as } \\
\text { research networks at national and international } \\
\text { levels. }\end{array}$ \\
\hline \multirow{2}{*}{ 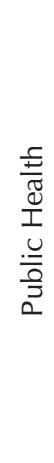 } & $\begin{array}{l}\text { Rodriguéz } \\
\text { BC, Chacón } \\
\text { AJM, } \\
\text { González } \\
\text { TR }\end{array}$ & $\begin{array}{l}\text { Mexico/ } \\
2010\end{array}$ & $\begin{array}{l}\text { To reduce the consumption } \\
\text { of alcohol and other drugs in } \\
\text { college students by providing } \\
\text { tools to increase protective factors } \\
\text { and reduce risk factors. }\end{array}$ & $\begin{array}{l}\text { Volunteers, } \\
\text { enrolled at the } \\
\text { University with } \\
19-30 \text { years of age, } \\
\text { specialists }\end{array}$ & $\begin{array}{l}\text { Workshop with 6-month duration, in a } \\
\text { total of } 15 \text { sessions, and evaluation through } \\
\text { questionnaires. Interaction with the active } \\
\text { participation of the participants was promoted, } \\
\text { and reduction of risk factors and increase of } \\
\text { protective factors were verified. }\end{array}$ \\
\hline & $\begin{array}{l}\text { Higgins SJW, } \\
\text { Lauzon LL, } \\
\text { Yew AC, } \\
\text { Bratseth CD, } \\
\text { McLeod } N^{(27)}\end{array}$ & $\begin{array}{l}\text { Canada/ } \\
2010\end{array}$ & $\begin{array}{l}\text { To promote welfare on } \\
\text { campus. }\end{array}$ & University students & $\begin{array}{l}\text { Health promotion course with 13-week duration, } \\
39 \text { hours in total, during the course of } 2 \text { years. } \\
\text { An increase of knowledge at nutritional level, of } \\
\text { social and environmental welfare, of self-care, of } \\
\text { occupational and emotional management were } \\
\text { verified. A health and welfare-themed race was } \\
\text { implemented. }\end{array}$ \\
\hline
\end{tabular}


Chart 1 (concluded)

\begin{tabular}{|c|c|c|c|c|c|}
\hline & Author & $\begin{array}{l}\text { Country/ } \\
\text { Year }\end{array}$ & Objectives & Participants & Interventions/Program \\
\hline 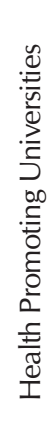 & $\begin{array}{l}\text { Dooris M, } \\
\text { Doherty } \mathrm{S}^{(8)}\end{array}$ & $\begin{array}{c}\text { United } \\
\text { Kingdom/ } \\
2010\end{array}$ & $\begin{array}{l}\text { To explore the potential for the } \\
\text { creation of a National HPU } \\
\text { program that may contribute to } \\
\text { health, welfare and sustainable } \\
\text { development. }\end{array}$ & $\begin{array}{l}\text { Academic } \\
\text { association of } \\
\text { Higher Education } \\
\text { students, the } \\
\text { Universities' Health } \\
\text { and Innovation } \\
\text { Department; Higher } \\
\text { Education Academy; } \\
\text { Ministry of Higher } \\
\text { Education; National } \\
\text { Union of Students; } \\
\text { Royal Society of } \\
\text { Public Health } \\
\text { Universities }\end{array}$ & $\begin{array}{l}\text { Implementation of a national program for } \\
\text { Health Promoting Universities. } \\
\text { Conducting of workshops in partnership with } \\
\text { the National Network of Healthy Universities, } \\
\text { in order to present the results of the research } \\
\text { developed at national level with partners } \\
\text { and Universities. It resulted in the creation of } \\
\text { standards with an impact on the health and } \\
\text { welfare of all students and of the rest of the } \\
\text { academy, through education, research and } \\
\text { transferring of knowledge and institutional } \\
\text { practices, with benefits also for Public Health. }\end{array}$ \\
\hline
\end{tabular}

Chart 2 - Characterization of the programs implemented in the studies of the articles included in the integrative review

\begin{tabular}{|c|c|c|c|c|c|c|c|c|c|c|c|c|c|c|c|c|c|c|}
\hline \multicolumn{2}{|c|}{ Numeric referencing of the articles } & 7 & 13 & 14 & 15 & 16 & 17 & 18 & 19 & 20 & 21 & 22 & 23 & 24 & 25 & 26 & 27 & 8 \\
\hline \multicolumn{2}{|c|}{ Analysis criteria } & \multicolumn{10}{|c|}{ Health Promotion } & \multicolumn{6}{|c|}{ Public Health } & HPU \\
\hline \multirow{7}{*}{ 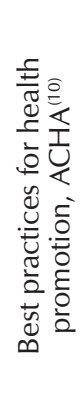 } & $\begin{array}{l}\text { 1. Integration with the mission of the higher } \\
\text { education institution }\end{array}$ & $X$ & $x$ & - & - & - & - & - & $x$ & $\mathrm{X}$ & $x$ & - & - & $x$ & - & - & - & $X$ \\
\hline & 2. Practice of socio-ecological approach & $X$ & $\mathrm{X}$ & $\mathrm{X}$ & - & - & - & - & $x$ & $X$ & - & - & - & - & - & - & $X$ & $X$ \\
\hline & 3. Collaborative practice & $X$ & $x$ & - & - & - & - & - & $x$ & $x$ & - & - & - & $x$ & $x$ & - & - & $X$ \\
\hline & 4. Cultural competence & - & - & $x$ & - & - & - & - & $X$ & - & - & - & $x$ & $X$ & - & - & - & - \\
\hline & 5. Theory-based practice & - & $X$ & - & - & $X$ & - & $x$ & $x$ & - & - & $x$ & - & - & - & $X$ & $X$ & - \\
\hline & 6. Theory-based practice & - & - & - & - & - & - & - & $X$ & $\mathrm{X}$ & - & - & - & $x$ & - & - & $X$ & - \\
\hline & 7. Professional enhancement and ethical practice & $X$ & - & - & - & - & - & - & $X$ & $\mathrm{X}$ & - & - & - & - & - & - & - & - \\
\hline \multirow{5}{*}{ 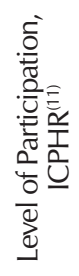 } & 1. Participatory action-research & - & - & - & - & - & - & - & $X$ & $\mathrm{X}$ & - & - & - & $X$ & - & - & $X$ & - \\
\hline & 1.1. Contractual & - & - & - & - & - & - & - & - & - & $x$ & - & - & - & - & - & - & - \\
\hline & 1.2. Advisory & $x$ & - & - & - & - & - & - & - & $x$ & - & - & - & $x$ & - & - & $x$ & $x$ \\
\hline & 1.3. Collaborative & - & - & - & - & - & - & - & $X$ & - & - & - & - & - & - & - & - & - \\
\hline & 1.4. High school & - & - & - & - & - & - & - & - & - & - & - & - & - & - & - & - & - \\
\hline \multirow{3}{*}{ 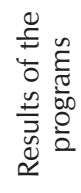 } & $\begin{array}{l}\text { 1. Results obtained in the implementation of the } \\
\text { programs included in the HPU }\end{array}$ & $x$ & - & $X$ & $X$ & 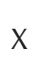 & $\mathrm{X}$ & $\mathrm{X}$ & $x$ & $x$ & $X$ & - & $X$ & $x$ & $x$ & $x$ & $\mathrm{x}$ & $X$ \\
\hline & 2. Impact & $x$ & - & - & - & - & - & - & $\mathrm{X}$ & $x$ & $X$ & - & - & - & $X$ & - & $X$ & $X$ \\
\hline & 3. Health policies & $X$ & $X$ & - & - & - & - & - & $X$ & $x$ & - & - & - & $X$ & $X$ & - & - & - \\
\hline
\end{tabular}

Note: HPU - Health Promoting University

\section{RESULTS}

The studies included in the review (17) were developed in 13 universities from different countries: Brazil (1), Canada (1), Colombia (1), Chile (1), China (1), Cuba (1), Spain (2), Ireland (1), Mexico (2), New Zealand (1), Portugal (2), the United Kingdom (1), and the United States of America (2) and published between 2002 and 2014.

One of the studies ${ }^{(8)}$ reports the opinion of 64 high education institutions and had as objective studying attitudes, possible support, benefits and challenges, potentialities and leadership in the implementation of HP programs in a university context. After the analysis of the projects included in the review, a simple and flexible conceptual framework was elaborated, focused on change processes through self-evaluation and through the applying of questionnaires and conduction of interviews with representatives of the institutions. The results were disclosed during workshops in partnership with the National Network of HPU.

Regarding the objectives of HP programs presented in the different studies, we have found that not all rely on a HP approach, but rather on a Public Health $(\mathrm{PH})$ approach: prevention of diseases ${ }^{(22)}$, implementation of the anti-tobacco law ${ }^{(24)}$, reduction in the consumption of alcohol, tobacco and other drugs $^{(25-26)}$ and use of condoms ${ }^{(23)}$, with prescriptive strategies such as workshops and lectures given by experts. It is important 
to note that one of the programs ${ }^{(27)}$ supported the promotion of welfare on campus. However, of the 855 initially participating students, only 60 took part in the final assessment, being reimbursed with $\$ 20$ each for their participation in the program.

The HP approach programs aimed at increasing general welfare $^{(7,15,17,19,21)}$, especially of the students, although some emphasized the practice of physical activity ${ }^{(22)}$, sexual health ${ }^{(14,16,18)}$ and improvement of the health support environment within the university community ${ }^{(20)}$. In these studies the dissonance between the practice and concept of HPU became evident, the criteria that define them as health promoting HEI not having been observed, considering that the programs were applied to small groups of volunteering student or classes and not to the institution as a whole.

\section{Best practices for health promotion (HP)}

After applying the criteria from $\mathrm{ACHA}^{(10)}$ in the six $\mathrm{PH}$ programs, it was found that only one study ${ }^{(24)}$ showed evidence of integration with the mission of the $\mathrm{HEl}$, whereas of the $10 \mathrm{HP}$ programs, $50 \%$ complied with this requirement ${ }^{(7,13,19-21)}$. The activities were either

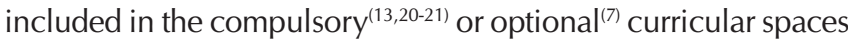
of the licentiate undergraduate program, or graduate courses and groups of voluntaries were established ${ }^{(19)}$.

As for the socio-ecological approach, in the six $\mathrm{PH}$ programs, only one ${ }^{(27)}$ established a focus group to identify barriers, by applying the PRECEDE-PROCEED model. Meanwhile, concerning HP programs, 50\% included multidimensional analysis practices ${ }^{(7,13-14,19-20)}$.

Some programs were based on theory-based practice. Among the $\mathrm{PH}$ programs, one followed the recommendations of the Disease Control and Prevention model ${ }^{(22)}$, another followed those of the Integral and Flexible Educational Model ${ }^{(26)}$, and yet another followed those of the PRECEDE-PROCEED model ${ }^{(27)}$. In the other programs categorized as HP, two referred to models ${ }^{(16,18)}$. In two studies, we identified evidences of the planning and creation of a scientific committee, but without reference to a HP model ${ }^{(13,19)}$.

Of the six $\mathrm{PH}$ programs, in two studies we verified evidences of collaborative practice ${ }^{(24-25)}$; in the HP programs, there was participation of several departments of the university ${ }^{(13,19-20)}$, of the entire educational community ${ }^{(7,19)}$ and of partners from various social levels ${ }^{(7,19-20)}$.

Of the $\mathrm{PH}$ programs analyzed, only two showed evidences of concern with cultural competence ${ }^{(23-24)}$ : one for allowing the expression of opinions and concerns about the new tobacco law, and another for addressing the fact sexual health workshops take genre into consideration. In one of the HP programs ${ }^{(14)}$, the strategies included group techniques of critical reflection for the raising of awareness on cultural diversity and, in another ${ }^{(19)}$, concern with the recruitment of elements from minority groups and with poor economic conditions became apparent.

In the dimension of theory-based practice, we verified that one of the programs ${ }^{(24)}$ carried out a review of the literature and other two ${ }^{(19,27)}$ featured the application of instruments TestWell Survey and Health Path, respectively. Another program ${ }^{(20)}$ referenced evaluation instruments that had been previously validated, though this reference was not clear. The programs which evidenced professional enhancement and ethical practice were unanimously categorized as $\mathrm{HP}^{(7,19-20)}$, but indicated the training of professors only.

\section{Level of participation of the parties involved}

Despite the identified studies having involved professors, students, non-teaching staff and representatives of the community, we found no evidence that the HP programs could be fully categorized as participatory action-research. Of the six $\mathrm{PH}$ programs, one $\mathrm{e}^{(24)}$ developed a collaborative work with the participation of all members of the educational community, and another $^{(27)}$ mentioned the use of the participatory model and established a focus group to identify barriers.

Some studies ${ }^{(19-20)}$ featured strategies of participatory research, having included the promotion of double empowerment based on the gains obtained in health and welfare within the academic community, through its mobilization and participation, and in particular through the action of volunteering students who worked with the researchers.

Through the analysis of the articles, it was possible to verify that, in one of the studies ${ }^{(21)}$, the relationships established between the participants were of the contractual kind, seeing that 65 students were "contracted" to act as informants. In the remaining articles ${ }^{(7-8,20,24,27)}$, participants were invited to express and share their opinions, before and after the development of the HP projects, to provide data for their evaluation, and also collaborated in the identification of their needs. However, strategies were not elaborated in groups so as to improve the context or overcome barriers, which denotes the advisory nature of the relationship between researchers and participants. The collaborative process was only identified in one study ${ }^{(19)}$.

\section{Results of the intervention programs}

In compliance with the framework proposed for this study (HP or $\mathrm{PH}$-inspired programs) we identified the results expressed in relation to the target subjects, to the $\mathrm{HEI}$ and to health policies.

Of the six $\mathrm{PH}$ programs, five ${ }^{(23-27)}$ divulged their results, some of which focused on the target subjects only (small samples), whereas others focused on the education community. One program ${ }^{(23)}$ evaluated the satisfaction with the use of the female condom, as well as the advantages and obstacles identified in using it, with a group of 83 students from three campus of the University. No references were found in relation to the efficiency of the use of this type of sexual protection, neither to the impact of this knowledge on the remaining students. In two programs ${ }^{(25-26)}$, the interventions aimed at reducing the consumption of alcohol and other drugs in college students and in the community, through the implementation of workshops with 15 sessions each, to enhance the protective factors and reduce risk, in addition to regular health education campaigns, support groups, health fairs and individualized consultations. These interventions promoted a $74 \%$ reduction in the risk factors, a $70.3 \%$ increase in the protective factors ${ }^{(26)}$, and generated mobilization policies within the academic community, as well as greater coordination with local structures, and also, national and international research networks ${ }^{(25)}$.

The program ${ }^{(27)}$ that featured the PRECEDE-PROCEED model to promote welfare in three university campuses held a HP course, for 2 years, and came to the conclusion that the 60 students who participated in the final evaluation, after eight months, exhibited health gains.

Of the ten HP programs, only one did not present evidence of its results $^{(13)}$, and four reported results in the target subject(s) only: 15 
master's students ${ }^{(14)}, 34$ licentiate undergraduate students ${ }^{(17)}, 7$ university students in the experimental group and 6 in the control group ${ }^{(18)}$.

Three programs ${ }^{(7,19-20)}$ showed evidences of results in the three spheres: target subjects, institutional aspects and health policies. In one of the studies ${ }^{(7)}$, the program aimed at adopting or reformulating the University's policies, having as objective: promoting the health of the entire academic community; creating a healthy physical and social environment; developing personal health skills through peer education; establishing health services and implementing activities in the community with the participation of the students. In addition, they incorporated HP activities on mental health, aimed at the students, in the annual plan of the university and of the courses, with allocation of credits.

In one of the studies, we found an intervention program ${ }^{(19)}$ which was based on a 12-week project, with weekly participatory sessions, concerning decision-making strategies and problemsolving. An initial and a final evaluation of the participants' state of health was performed. The study mentions that all participants cooperated in the process of planning of the health education strategies, and that they answered a questionnaire on health risk assessment. A reduction in addictions and mental/ emotional disorders, along with an increase in the knowledge of ways of transmission of STD/AIDS, were both verified. It was recognized that health and welfare within the context of the HPU contribute positively to the pillars of the institution - quality, recruitment, experience, differentiation, productivity, success and sustainability, as they educate the leaders of tomorrow.

Finally, a program ${ }^{(20)}$ focused on environmental management to reduce the production of waste emerged. A working group made up of managers from the university, volunteering student, academic and non-academic staff was formed, with general mobilization. Waste reduction and energy saving were quantified and allowed financing $50 \%$ of the program. An environment club was also created, and the research was incorporated into the academic activities, integrating various disciplines. The signing of a protocol of environmental responsibility in universities consolidated the collaboration with a coffee shop company, as well as the involvement of multiple departments/disciplines.

The creation of health policies was the component that was referred to the most in the three programs that integrated the highest number of criteria under analysis ${ }^{(7,19-20)}$, showing greater consonance with the requirements of the HPU. These articles synthesized the knowledge assimilated after the implementation of multidimensional programs targeted at the entire academic community and the environment. All of them referred to the participation of the educational community and of partners such as local authorities, external health institutions and expert advice in health education or in the designing of the HP program.

\section{DISCUSSION}

Of the seventeen studies that referred to intervention strategies, six (35\%) fit the public health guidelines and, therefore, constituted themselves as guiding strategies that were not very comprehensive and highly normative. Of the programs that fit the HP approach, it was possible to identify that only three encompassed the university as a whole and complied with the requirements of health promoting contexts, featuring approaches akin to participatory-action research.

We would like to point out that universities educate students who are or will be professionals and policy makers with the potential to influence the conditions that affect the quality of life of people ${ }^{(5)}$. Thus, by developing a pedagogical-political research project aimed at HP, they can extend the knowledge and the commitment to health of a large number of people, seeing as they provide courses in various fields of knowledge. This includes not only the healthcare professionals' the commitment, but also of students and professors from the courses of social, technological and human sciences. In academic terms, transforming an institution in a health promoting context has the potential to strengthen discussions on health in various academic fields, and to enhance the credibility of innovative researches in the field, as well as to provide support for a change in the focus of researches towards multilevel and interdisciplinary actions ${ }^{(2-3)}$, developed with the intent of solving problems that impact the quality of life of people, and of combating social and health inequalities.

Other studies ${ }^{(7-8,19-20)}$ reported programs that encompass the entire academic community and provide opportunities for the university to influence the health and quality of life of its members, as well as of the external community, favoring greater knowledge and reaffirming citizenship. These programs transformed universities and their comprehensive community and contribute to improving health in three distinct areas: promoting working spaces for the learning and healthy experiences of students, employees and other target subjects; expanding the importance of health, HP and public health in teaching and research; and developing alliances and partnerships for community mobilization.

Problematizing HP-based education promotes an intersectoral and interdisciplinarity approach. This intersectorality, when incorporated into the education of health professionals, is in compliance with the guidelines of the World Health Organization, which has been propagating the concept and supporting the strategy of creation of healthy environments ${ }^{(28)}$. Including HP activities in the process of education of new professionals in all fields favors integral education, seeing as there is encouragement to responsible professional practice, in line with the social reality ${ }^{(1,29)}$. Universities have the responsibility to facilitate the education of students in the control of their own health and welfare ${ }^{(30)}$, in order to help them make the best decisions possible ${ }^{(31)}$.

The Peer-Education Engagement \& Evaluation Research (PEERIESS) proposal aims to develop benchmarks of best practices in peer education and health promotion, in a community context, involving Portuguese-speaking young people and students of the higher education course in Nursing (from Portugal, Angola, Brazil and Cape Verde). PEER-IESS is a participatory actionresearch model in which, through a "seed group", a higher education institution is mobilized to generate health-promoting environments.

It is important to validate this model while considering that, from the education of a group of students, professors, non-teaching staff and community leaders, it is possible to assess their health needs, which substantiate the designing of HP strategies that focus on procedures involving dialogue and creative ways to mobilize the community. Therefore, it is a collaborative process that may 
be applied to Nursing schools, in which researchers, students and people from the community work together to develop HP projects.

\section{Study limitations}

We have verified that most of the studies analyzed were not developed in institutions of higher education in Nursing. Only one of them involved an institution of higher education characterized as a Health Promoting University.

\section{Contributions to the Nursing field}

This integrative review can contribute to the construction of a benchmark for validation of a participatory action-research model aimed at the transformation of higher education Nursing schools within a health promoting context. This premise has greater relevance for higher education in Nursing considering that, while attending the course, students already hold knowledge associated with the field of HP, due to its impact in determining the prevalence of society's health risk behaviors and in the promotion of healthy lifestyles ${ }^{(31)}$. Such findings fully apply to education in Nursing since, for these students to become competent professionals in the future, they should firstly acquire healthy lifestyles, so they can then provide care to other people.

\section{CONCLUSION}

HP strategies do not always result from a synergy of planned educational, political, legislative or organizational actions that support life habits and conditions which are favorable to the health of individuals, groups or communities and which contribute to the increase of literacy in health, to the reduction of risk behavior and to improving the physical and social environment. The 17 programs analyzed evidenced these benefits, especially those based on assumptions from HP, more so than from public health.

The scientific evidence concerning intervention programs in higher education has little relation to the requirements of health promoting contexts, of participatory action-research, which is reflected in the level of participation of the parties involved, both in programs with a HP-based approach as in programs with a $\mathrm{PH}$-based approach. Few programs include the criteria of best practices for HP in higher education, such as professional enhancement and practice ethics, cultural skills and evidence-based practice.

This review also suggests that it is necessary to invest more in the publication of the results of health promotion interventions within the university context.

\section{REFERENCES}

1. International Conference on Health Promoting Universities \& Colleges. Okanagan Charter: an international charter for health promoting universities and colleges[Internet]. 2015 [cited 2016 Dec 27];1-11. Available from: http://hdl.handle.net/2429/54938

2. World Health Organization-WHO. Healthy Settings[Internet]. Geneve: WHO; 2016 [cited Dec 27 2016]. Available from: http:// www.who.int/healthy_settings/en/

3. World Health Organization-WHO. 9th Global conference on health promotion: Global leaders agree to promote health in order to achieve Sustainable Development Goals[Internet]. Geneve: WHO; 2016 [cited Dec 27 2016]. Available from: http://www.who. int/mediacentre/news/releases/2016/conference-health-promotion/en/

4. Dooris M, Wills J, Newton J. Theorizing healthy settings: a critical discussion with reference to Healthy Universities. Scand J Public Health[Internet]. 2014 [cited 2016 Dec 27];42(15):7-16. Available from: http://dx.doi.org/10.1177/1403494814544495

5. Dooris M, Doherty S, Orme J. The application of salutogenesis in universities. In: Mittelmark MB, et al. The Handbook of Salutogenis[Internet]. England: Springer; 2017 [cited 2017 May 03];237-45. Available from: http://eprints.uwe.ac.uk/29811

6. Sirakamon S, Chontawan R, Akkadechanun T, Turale S. An etnography of health-promoting faculty in a Thailand university. Health Promot Int[Internet]. 2013[cited 2016 Aug 17];(25):1-10. Available from: http://heapro.oxfordjournals.org/content/early/2013/11/25/ heapro.dat083.full.pdf + html

7. Xiangyang T, Lan Z, Xueping M, Tao Z, Yuzhen S, Jagusztyn M. Beijing health promoting universities: practice and evaluation. Health Promot Int[Internet]. 2003 [cited 2015 Sep 17];18(2):107-13. Available from: http://heapro.oxfordjournals.org/content/18/2/107. full.pdf + html. doi:10.1093/heapro/18.2.107

8. Dooris M, Doherty S. Healthy Universities: time for action: a qualitative research study exploring the potential for a national programme. Health Promot Int[Internet]. 2010[cited 2015 Sep 17];25(1):94-106. Available from: http://heapro.oxfordjournals.org/ content/25/1/94.long. doi: 10.1093/heapro/daq015

9. Sharma M. Theoretical foundations of health education and health promotion. USA: Jones \& Bartlett Learning; 2016.

10. American College Health Association. Standards of practice for health promotion in higher education. 3 ed. Hanover; 2012.

11. International Collaboration on Participatory Health Research-ICPHR. Position Paper 1: what is participatory health research? Version: May 2013. Berlin: ICPHR; 2013.

12. Souza MT, Silva M, Carvalho R. Revisão integrativa: o que é e como fazer. Einstein[Internet]. 2010 [cited 2016 Aug 17];8(1):10206. Available from: http://www.scielo.br/pdf/eins/v8n1/pt_1679-4508-eins-8-1-0102.pdf

13. Prieto RA. Modelo de promoción de la salud, con énfasis en actividad física, para una comunidad estudiantil universitaria. Rev Salud Pública[Internet]. 2003[cited 2015 Sep 17];5(3):284-300. Available from: http://dx.doi.org/10.1590/S0124-00642003000300005 
14. Moskovics JM, Calvetti PÜ. Formação de multiplicadores para a prevenção das DST/AIDS numa universidade espanhola. Psicologia: Ciência e Profissão. [Internet] 2008 [cited 2015 Sep 17];28(1):210-17. Available from: http://www.scielo.br/pdf/pcp/ v28n1/v28n1a16.pdf

15. Tavares J, Pereira A, Gomes AA, Cabral AP, Fernandes C, Huet I, et al. Estratégias de promoção do sucesso académico: uma intervenção em contexto curricular. Anál Psicol [Internet]. 2006 [cited 2015 Sep 17];24(1):61-72. Available from: http://www. scielo.br/pdf/pcp/v28n1/v28n1a16.pdf

16. Cabrera RA, Ramos GS, Palú MEC, Cáceres BP. Estrategia educativa sobre promoción en salud sexual y reproductiva para adolescentes y jóvenes universitarios. Rev Cubana Salud Pública[Internet]. 2013[cited 2015 Sep 17];39(1):161-74. Available from: https://scielosp.org/pdf/rcsp/2013.v39n1/161-174/es

17. Mello MVO, Bernardelli Jr B, Menossi BRS, Vieira FSF. Comportamentos de risco para a saúde de estudantes da Universidade Estadual do Norte do Paraná (Brasil): uma proposta de intervenção online. Ciênc Saúde Colet[Internet]. 2014 [cited 2015 Sep 17];19(1):159-64. Available from: http://www.scielo.br/pdf/csc/v19n1/1413-8123-csc-19-01-00159.pdf

18. Alvarez M, Oliveira M. Programa de prevenção do HIV/SIDA para estudantes universitários: um estudo piloto. Rev Port Educ[Internet]. 2000[cited 2015 Sep 17];20(2):183-211. Available from: http://www.redalyc.org/articulo.oa?id=37420207

19. Reger B, Williams K, Kolar M, Smith H, Douglas J. Implementing University-Based Wellness: a participatory planning approach. Health Promot Pract[Internet]. 2002 [cited 2015 Sep 17];3(4):507-14. Available from: http://hpp.sagepub.com/content/3/4/507. abstract. doi:10.1177/152483902236721

20. Mason IG, Brooking AK, Oberender A, Harford JM, Horsley PG. Implementation of a zero waste program at a university campus. Resourc Conserv Recycl[Internet]. 2003 [cited 2015 Sep 17];38(4):257-69. Available from: http://dx.doi.org/10.1016/ S0921-3449(02)00147-7

21. Healy D, Mc-Sharry P. Promoting self-awareness in undergraduate nursing students in relation to their health status and personal behaviours. Nurse Educ Pract[Internet]. 2011[cited 2015 Sep 17];11(4):228-333. Available from: http://www.nurseeducationinpractice. com/article/S1471-5953(10)00135-6/abstract. doi:10.1016/j.nepr.2010.10.009

22. Murphy BL, Dipietro NA, Kier KL. Knowledge and use of folic acid among college women: a pilot health promotion program led by pharmacy students and faculty. Pharmacy Practice[Internet]. 2010 [cited 2015 Sep 17];8(4):220-5. Available from: http://dx.doi. org/10.4321/S1886-36552010000400003

23. Lameiras M, Ricoy MC, Carrera MV, Failde JM, Núñez AM. Evaluación del uso del preservativo femenino promovido desde un programa de educación para la salud: un enfoque cualitativo. Saúde Soc[Internet]. 2011 [cited 2015 Sep 17];20(2):410-24. Available from: http://dx.doi.org/10.1590/S0104-12902011000200013

24. Cabieses B, Muñoz M, Zuzulich S, Contreras A. Cómo implementar la nueva ley chilena antitabaco al interior de la universidad. Rev Panam Salud Publica[Internet]. 2008 [cited 2015 Sep 17];23(5):361-8. Available from: http://dx.doi.org/10.1590/S1020-49892008000500013

25. Mendoza AZ. Actividades realizadas en enseñanza a traves del programa de promoción de la salud y prevención de adicciónes en el periodo 2003-2004. Rev Latino-Am Enfermagem[Internet]. 2005 [cited 2015 Sep 17];13(spe2):1201-1206. Available from: http://dx.doi.org/10.1590/S0104-11692005000800015

26. Rodriguéz BC, Chacón AJM, González TR. Prevención integral de consumo de alcohol y drogas en estudiantes universitarios: una propuesta de intervención grupal. Acta Colombiana Psicol [Internet]. 2010 [cited 2015 Sep 17];13(2):19-33. Available from: https://dialnet.unirioja.es/descarga/articulo/3636173.pdf

27. Higgins SJW , Lauzon LL, Yew AC, Bratseth CD , McLeod N. Wellness 101: health education for the university student. Health Educ[Internet]. 2010[cited 2015 Sep 17];110(4):309-27. Available from: http://dx.doi.org/10.1108/09654281011052655

28. World Health Organization-WHO. WHO's Global School Health Initiative: Health Promoting Schools: a healthy setting for living, learning and working[Internet]. Geneve: WHO. 1998 [cited 2016 Aug 17]. Available from: http://www.who.int/school_youth_health/ media/en/92.pdf

29. Tsouros A, Dowding G, Thompson J, Dooris M. Health promoting universities: concept, experience and framework for action. Copenhagen: World Health Organization; 1998.

30. Holt M, Powell S. Healthy Universities: a guiding framework for universities to examine the distinctive health needs of own students population. Perspect Public Health[Internet]. 2016[cited 2016 Dec 27];20(21):1-6. Available from: http://dx.doi. org/10.1177/1757913916659095

31. Polat U, Ozen S, Kahraman BB, Bostanoğlu H. Factors Affecting Health-Promoting Behaviors in Nursing Students at a University in Turkey. J Transcul Nurs[Internet]. 2016 [cited 2016 Dec 27];27(4):413-9. Available from: http://dx.doi.org/10.1177/1043659615569536 